\title{
The Function of Public Relations of Language Development and Construction Agency, Ministry of Education and Culture Republic Indonesia in Publishing the Language Preservation Program
}

\author{
Veronica Pratiwi ${ }^{1}$, Liza Dwi Ratna Dewi ${ }^{2}$ \\ \{vero.pratiwi97@gmail.com¹ ${ }^{1}$, liza.dwiratna@budiluhur.ac.id ${ }^{2}$ \}
}

Faculty of Communication, Universitas Budi Luhur, Jl. Ciledug Raya, Jakarta, Indonesia ${ }^{1,2}$

\begin{abstract}
Indonesia has 742 languages from 478 tribes, but the language and literature existed in Indonesia today will soon become extinct. Indonesia Government to protect the language and literature established the Agency of Language and Development and Reconstruction under the Ministry of Education and Culture of Republic Indonesia. The purpose of this research was to describe the function of public relations of the Agency of Language and Development and Reconstruction in publishing the program of language preservation. The study used concept of public relations functions by Cutlip and Center. The research method used was descriptive qualitative. The results of this study indicated the work performance of the public relations of the Agency of Agency of Language and Development and Reconstruction was poor in doing publication. The cause was due to lack of communication with the content providers (Preservation Agency) and content editors (Language Editor). In addition, in bureaucracy, the Public Relations could not directly involve in the language preservation program. The Public Relations department did not participate in the process of drafting, implementing, and evaluating the program.
\end{abstract}

Keywords: Government public relations, Publications, Language, Literature.

\section{Introduction}

Language and cultural are related and there would be connections between them [1]. Indonesia is a country with cultural diversity and one national language. Now we are in globalization era with english language as the medium. "The diversity of Indonesian culture can be seen from the number of languages that is as much as 742 languages from 478 tribes" [2]. Languages and literature in Indonesia today can be said to have entered the endangered stage. The diversity of language and literature today needs to be protected and preserved for future generations in knowing each local language. In response to this situation, in 2012 Indonesian government established Language Development and Reconstruction Agency under the Ministry of Education and Culture Republic Indonesia. The Agency of Language Development and Reconstruction of the Ministry of Education and Culture Republic of Indonesia which hereinafter will be abbreviated as Language Agency aims to protect and preserve the language and literature. Based on 2016 mapping by Language Development and Reconstruction Agency under Ministry of Education and Culture Republic of Indonesia, at least 1 language and 3 literatures are categorized as critical; 5 languages and 3 literatures are 
categorized endangered; 3 literatures are categorized susceptible; 1 language and 1 literature are categorized setback. In total, 7 languages and 10 literature need to conservation and revitalization immediately. More than this, languages and literatures that categorized endangered are increasing every year.

Facing this situation the Language Agency need more publication to reach support from society in reach their goal. In 2015, the Language Agency has a PR section. Cutlip and Center state that the fuctions of public relations are: support the main management activity to reach collective goal; manage relationship between organization and stakeholders; identify things related to public opinion, public perception toward the organization; do public service and suggestion to top management; and create two ways communication between management and their stakeholders [3]. According to Amiruddin, the fuction of government public relations are: develop government policy; deliver public sevice and spreading mesagge or information relating to national policy and program to society; become proactive communicator and mediator in bridging institution interest and accomodating the aspiration; create condusif and dinamyc climate do to stability in political security and national development program [4]. Spreading mesagge or information can be said as publishing. In publishing, public relations officer can use and combine some media. Traditional such as event, exhibition, discussion, field visit; print media such as poster; mass media such as newspaper, radio, television; and new media such as website and social media [5]. The steps in publishing are: situasion analysis, objective set, formulate strategy, budgeting, staffing [6]. This study aims to evaluate how the functions of public relations, especially in publishing language and literature preservation programs

\section{Method}

The approach of this research is descriptive qualitative. According to Creswell (1998), Qualitative research is a complex picture, analysing words, detailed reports from respondents' views, and conducting studies on natural situations. Qualitative research is descriptive research and tends to use analysis with inductive approach [7],[8]. The sources of Primary data in this research are:The Head of Cooperation and Public Relations Agency, The Head of Preservation Division,Staff of Public Relations, andThe Chairman of " $11^{\text {th }}$ Annual of Communication Days" Saskta Bahasa as society representative who has interest in language and literature.

While the secondary data used in this study is from literature study, data of the institution, and internet. The data used by the researchers in this study are collected through: nonparticipant observation and in-depth interviews. Data collecting did at Public Relations Division of Agency of Language Development and Reconstruction of the Ministry of Education and Culture Republic Indonesia, Jl. Dasinapati Barat 4, Rawamangun, East Jakarta. Research did from September 15 th until December 15, 2018.

\section{Result and Discussion}

In preparation process, Public Relations of The Language Agency must follow strict bureaucratic procedures and should continue to coordinate with the language editor as editor of the publication's content. Often, the language editors are not on time in completing the 
edits, so it extend the time and hamper the publication process. Moreover, one of the factors that hampers this publication process is due to the Language Preservation that sometimes takes a long time and late in delivering the material or content to be published by the Public Relations of the Language Agency.

Then, after coordination, the Public Relations publishes the program through offline media (in the form of brochures and banners) and online media (official website and social media). The challenges faced in the process delivery of this information was because the Public Relations of Language Agency does not involved directly in creating the content information that will be delivered. The Public Relations only plays a role to spread the information. Another obstacles, according to the Public Relations agency, is the content presented by the Preservation Agency which is still less varied and not interesting.

In addition, the information delivery there is still not maximized, because not many people know the Language and Literature Preservation program. The information through offline media publications is still not widespread, so that only certain people that be able to receive the information related to the publication of the Language Agency. Meanwhile, in online media publication the official website and social media, such as Facebook, Twitter, Instagram, and Youtube are still not updated regularly, so then not many social media users know about the publication in social media.

In publishing process, the Public Relations of Language Agency spreads the information to the public. The Public Relations of Language Agency divides the target recipients through the publications used, i.e. offline and online publication media. The offline publication media is intended for those of middle age and above and those in an area where the internet stability is still not very good. This target type communicants usually tend to be easier to obtain information through offline media, including brochures and posters created by the Language Agency. While the online media is aimed at young people who are very active and Internet user, especially in using social media. This target type of communicants tend to be easier to obtain latest information quickly through social media.

One of the ways conducted by the Language Agency in spreading the publication of language and literature preservation program is by synergizing with universities. This activity is one way to target young communicants which is in the objectives of the Language Preservation Agency that have mapped the communicant targets for the publication of the language and literature preservation programs. In addition, at the end of the event the Language Agency also distributes some publications in the form of books, posters, and journals to several students and lecturers.

However, it is unfortunate to see and mapthe target recipients that carried out by the Preservation Agency is not maximal. In many cases, government officer already invited universities anda industries in Triple Helix formula [9]. Triple helix has become commont strategy of many governments in developing innovation policies [10]. That is because the mapping process had not been done by the Public Relations of the Language Agency by them self, but also academician and business actors. Instead, the function of viewing and mapping theseactorswere still done by the Language Preservation Agency, so the Public Relations of the Language Agency did not able to know and analyse it from where, who, and how the public will receive the publications related to the Language and Literature Preservation program.

Feedback process. After the Public Agency of the Language Agency disseminates information to the public, they will await the response from the public. The ideal response is not just about a person's attitude changes or the actions one takes after getting information. The response here is directed to the changes in knowledge and insight of someone who at first 
does not the information at all until understand it about the program of Language and Literature Preservation. In order to find out the responses that arise from the public, the Public Relations of the Language Agency can see it from the interactions and responses that appear in social media related to the publication that already published by Literature and Language Preservation programs. The problem of this process, the Public Relations of the Language Agency has not been able to know exactly how to see the knowledge change from the public who obtained the information through offline media, because the Public Relations of the Language Agency did not go along directly to the field to follow and establish the program of Language and Literature Preservation in various areas. In the implementation of this program, only the Language Preservation Agency that go directly to the field and know the response of the public. Moreover, it is unfortunate that the Language Preservation Agency rarely reports or notifies the activities results and the public responses to the Public Relations of the Language Agency.

In fact, knowing the response from the public is one form of material evaluation of public relations Agency to evaluate the Language and Literature Preservation program. Meanwhile, the publications distributed by the Public Relations of the Language Agency have not been fully seen or known regarding the response from the public, especially on direct publications to local communities that joined in the program of Language and Literature Preservation. Thus, the Public Relation of the Language Agency is lack of evaluation material, although this evaluation is needed to improve the function of public relations to publish information better than before.

Based on the above discussion, the researchers can conclude that the Public Relations Agency's function in publicizing the program of Language and Literature Protection has not been maximized.

In addition, one of the factors that hampers this publication process is that language preservation Agency is sometimes takes a long time and late in delivering materials and contents to then be published by Public Relations Agency. Another reason is because not many people know the Language and Literature Preservation program due to the publication through offline media is still not widespread, so that only certain people who can receive the information related to the Publication Agency. Whereas, in the online publication media, including the official website and social media, such as; Facebook, Twitter, Instagram, and Youtube, were still not updated regularly or in other words, the publications presented are limited to old information, so not many people well known the Language Agency in social media.

So far, the function of viewing and mapping these actorsare still done by the Language Preservation Agency, so the Public Relation of the Language Agency cannot know and analyse it which from, who the public, and how the public will receive publications related to the Language and Literary Preservation program. On the contrary, from the organism side in this process, only some people know about the Language and Literature Preservation program. Most of the people who do not know about this program are among others; people whose profession except of writers, language lovers, academics, or in educational backgrounds and so on. Thus, indirectly it means that the publication is only known by the people of certain circles, and the publication has not reach the target intended because it is not suit the target marked and the initial goal to be achieved by the Language Agency. In this case Language Agency can learn from other countries that with triple helix, innovation system is not only complex function and interactions among various organizational actors, including government, enterprises, universities and research institutes, but also interplays between these actors and 
institutions which may include govermental policies and social norms especially when they are in different national and cultural context [10].

In the program implementation, only the Language Protection that go directly to the field and know the public response. Also, the Language Preservation Agency rarely reports or notifies the activities results and the public responses to the Public Relations of the Language Agency. In fact, knowing the response from the public is one form of material evaluation for Public Relations of the Language Agency in doing publication of the Language Preservation program better.

Furthermore, the researcher concludes that, the result of this research entitled "The Function of Public Relations of Language Development and Construction Agency, Ministry of Education and Culture Republic Indonesia in Publishing the Language Preservation Program" was not maximal and an evaluation was needed from all parties to improve the function of public relations of the Language Agency in the future.

\section{Conclusions}

The Function of the Public Relations of Language Development and Construction Agency had not maximum in publishing the Language and Literature Preservation Program. The Publications of Public Relations Agency of Language Development and Construction Agency, especially publications through conventional media such as brochures, books, and banners had not been maximize because the Public Relations did not directly involve in the implementation program of language and literature preservation. Thus, the Public Relations could not know how the response appeared in the public and could not know the evaluation needed from the publication.

\section{References}

[1]Fuli Liu, "The official trilogy and public paradox: understanding mainland Chinese policies of ELT on secondary level from the perspective of culture politics," Asian-Pacific Journl Second Foreign Lang. Educ., vol. 1: 11, no. The official trilogy and public paradox, p. 1, 2016.

[2]kominfo.co.id, "Indonesia Memiliki Kekayaan dan Keanekaragaman Budaya," October 10th, 2017. .

[3]B. W. N. Sari, Humas Pemerintahan. Yogyakarta: Graha Ilmu, 2012.

[4]Amiruddin, "Fungsi Humas Pemerintah Kota Binjai Dalam Penyebaran Informasi Kebijakan Publik," J. Penelit. Komun. dan Pembang., vol. 17 (2), p. 103, 2016.

[5]H. Widjaja, Komunikasi dan Hubungan Masyarakat. Jakarta: Bumi Aksara, 2008.

[6]Y. and Y. S. Iriantara, Public Relations Writting. Bandung: Simbiosa Rekatama, 2011.

[7]J. Noor, Metodologi Penelitian. Jakarta: Kencana Prenada Media Group, 2013.

[8]R. Kriyantono, Teknik Praktis Riset Komunikasi. Jakarta: Kencana Prenada Media, 2010.

[9]L. L. Etzkowitz H, “The Triple Helix - University-Industry-Government Relations: A Laboratory for Knowledge-Based Economic Development.," EASST Rev., vol. 14: 14-19, 1995.

[10]Yuzhuo Cai, "Implementing the Triple Helix model in a non - Western context: an institutional logics perspetive,” Tripel Helix J. .springopen.com, vol. 1.1, no. Implementing the Triple Helix model in a non-Western context., p. 2, 2014. 